\title{
'Word from the street': When non-electoral representative claims meet electoral representation in the United Kingdom
}

\section{David Judge}

\begin{abstract}
Taking the specific case of street protests in the United Kingdom - the 'word from the street' - this article examines recent (re)conceptualisations of political representation, most particularly Saward's notion of 'representative claim'. The specific example of non-electoral claims articulated by protestors and demonstrators in the United Kingdom is used to illustrate: the processes of making, constituting, evaluating and accepting claims for and by constituencies and audiences; and the continuing distinctiveness of claims based upon electoral representation. Two basic questions structure the analysis: first, why would the political representative claims of elected representatives trump the non-electoral claims of mass demonstrators? And, second, in what ways does the 'perceived legitimacy' of the former differ from the latter?
\end{abstract}

Keywords: representation; representative claims; parliamentary democracy; street protests; parliament

\section{Introduction}

It has become something of a truism that the 'standard account' of representative democracy has now been 'stretched to breaking point' (Urbinati and Warren, 2008, p. 390). There is broad acknowledgement that 'practices of democratic representation increasingly go beyond electoral venues', and this has led to the 'most remarkable development [of] the proliferation of representative claims that cannot be tested by election' (ibid., p. 403). In response, a 'new frontier' of democratic theory has been opened up beyond 'a purely electoral rendering of democracy and representation' (ibid., p. 402). A particularly prominent role in staking out the boundaries of this new theoretical frontier has been played by Saward $(2006,2010)$ in prospecting the notion of 'the representative claim'.

Saward (2010, p. 140) starts from the premise 
that one of the 'most critical key assumptions over four decades' has been that 'representative democracy is all about elections, and only elected officials can be classed as democratic representatives'. In this sense 'representative democracy as a political system in which elected officials make collective decisions for constituents is too familiar', and what is needed, therefore, is to 'make democracy strange again' (ibid., p. 167). The strangeness is to be found, for Saward, in non-electoral forms of representation. In essence, 'political representation is a world of claim-making rather than the operation of formal institutions' (ibid., p. 43). In which case it is difficult to sustain 'a binary distinction between democratic representation based on election, on the one hand, and other-than-democratic representation based on a different mode of selection, on the other' (ibid., p. 25).

In making the case that political representation is a process of claim-making rather than a fact established by institutional election or selection, Saward seeks to map out new theoretical territory and to blur the distinction between electoral and non-electoral representation. This article aims to prospect the contours of this map, and uses Saward's (2010, p. 1) dictum - that 'political ideas and practices are more closely intertwined than we often think' - as a compass to examine both the theory and practice of political representation in the United Kingdom. The specific example of non-electoral claims articulated through 'the word from the street' - 'based on massive and tangible demonstration of popular support' by protestors and demonstrators - is used to illustrate: first, the processes of making, constituting, evaluating and accepting claims for and by constituencies and audiences; and second, the continuing distinctiveness of claims based on electoral representation. Two basic questions structure the analysis. These reformulate the questions posed initially by Beetham (2003) in the wake of the massive demonstrations throughout the United Kingdom against the invasion of Iraq in 2003:

[A] central question of representative democracy which goes far beyond Britain: [is] about the proper relationship between an elected parliament and government on one side and organised public opinion on the other. The question was posed most starkly by the unprecedented mass demonstrations against the war ... Is it legitimate for a democratically elected government to ignore public opinion in this way? Is it democratic for it to do so? (p. 597)

Rephrased in terms of representative claims, these questions become: first, why would the political representative claims of elected Members of Parliament trump the non-electoral claims of mass demonstrators? And, second, in what ways does the 'perceived legitimacy' of the former differ from the latter? The discussion is advanced in three stages: first, the notions of 'representative claim' and 'nonelectoral representation' are outlined; second, the distinction to be drawn between electoral and nonelectoral representative claims is clarified; and third, the utility 
of such new perspectives in understanding the practice of UK representative processes is assessed. ${ }^{1}$

\section{Representative Claims}

Saward's (2010, pp. 8-9) starting point for his 'fundamental reappraisal of the idea of political representation' is a critique of the 'avoidable limitations in our current thinking about political representation'. The key limitations of 'the prevailing orthodoxy' include: too strong a focus on the definition of representation (what it is), rather than the constitution of representation (what it does); downplaying or ignoring the constitutive dimension of representation; allowing a normative orientation to delimit what is accepted as counting as representation, particularly what counts as democratic or legitimate representation; the overemphasis of forms, roles and typologies of representation; focusing too closely upon formal, and especially electoral representation to the exclusion of other modes of representation; the frequent assumption that the national level remains the sole or defining site of representation; and, on occasion, disengagement from real-world problems and issues that have an impact on ideas of representation. Of these seven limitations, the main focus of attention here is upon 'what counts as democratic or legitimate representation' and the privileging of formal, electoral representation to the supposed exclusion of non-electoral modes of representation.

Saward's list of limitations is derived from a detailed critique of the work of influential contemporary theorists, most particularly Pitkin (1967), Mansbridge (2003) and Rehfeld (2006). The scope of this critique extends beyond the immediate concerns of this article, but the main divergences between Saward and the other named theorists stem from his desire to move beyond Pitkin's (1967, p. 209) notion of 'substantive acting for others', with its implicit unidirectional relationship between representative and represented, and its emphasis on the identity of the former rather than the latter (Saward, 2010, p. 16), towards a meaning that includes 'deeper processes of constructing the represented or that which needs to be represented' (ibid., p. 10 emphasis in original). Similarly, he wishes to build upon Mansbridge's categorisation of representation - promissory, anticipatory, gyroscopic and surrogate - to argue that representation 'need not be based on election in order to be representation', or need not be formal (ibid., p. 22). Equally, he identifies Rehfeld's (2006, p. 5) notion of an 'audience' (as 'the relevant group of people who must recognise a claimant as a representative'), as a way of understanding that political representation arises because a relevant audience accepts a representative's claims in some way (Saward, 2010, p. 48). Although Saward (2010, pp. 32-34)

concedes that Mansbridge and Rehfeld (with others such as Phillips (1995), Young (2000), Goodin (2004) and Urbinati (2006)) offer valuable increments in the understanding of representation, he maintains that there is still a need to "go further 
than the existing work' in recognising the constitutive dimension of representation, exploring what is going on in representation rather than what its forms might be, and accepting that the level of the nation state is not 'the sole or defining site of political representation'. Most significantly, for present purposes, one overriding contention is that: 'legislatures, formal territorial constituencies and the institutions they support are not all that matters to political representation ... To define representation in terms of elective and legislative representation is to commit one version of what Holden calls the "definitional fallacy"' (ibid., p. 31).

\section{Representation for what purpose? Non-elected representation claim-making, claim-receiving and claim-accepting}

In calling for a 'radical rethink of the status of elections and voting with regard to democratic representation', Saward (ibid. p. 109) calls for the recognition of the 'inevitability, even the democratic necessity, of a wide array of other, nonelective representative claims in complex contemporary democratic politics'. These include: group morality and ties of tradition; 'permanent interests' articulated by senior bureaucrats; specialist expertise, surrogacy for wider interests; descriptive similarity as in 'mirroring'; stakeholding; self-representation of the interests of, for example, future generations or non-human life; and the particular focus of this article, a claim based on 'massive and tangible demonstration of popular support' - the word from the street (ibid., p. 99).

The essence of Saward's (ibid., p. 43) view is that 'political representation is a world of claim-making rather than the operation of formal institutions'. Claim- making consists of five interconnecting dimensions: maker, subject, object, referent and audience. A 'maker', either as an individual or a collective actor, constructs or makes claims; a 'subject' is a signifier and stands for an object; a referent is an idea of the thing being represented; and an 'audience' receives the claims made - and accepts, rejects or ignores them. Ultimately, claim-makers are attempting 'to achieve acceptance and other effects through the conceptions of subject and object they construct' (ibid., p. 48).

Saward asks: what is a representative claim about? The answer is relatively clear: 'Representative claims are invariably constitutive claims, they construct in some measure the groups they purport to address (audience) along with the groups they purport to speak for or about (constituency)' (ibid., p. 54). Yet, 'representative claims can only work, or even exist, if audiences acknowledge them in some way' (ibid., p. 48). In this sense, there is an affinity with Urbinati's $(2006$, p. 6) view that 'representation is a comprehensive filtering, refining and mediating process of political will formation and expression'. Although Urbinati (2006, p. 42) is willing to associate political representation with the 'power to make decisions' and that these decisions 'are collective in the sense that they apply to all the members of the body 
politic', Saward (2010, p. 138) insists that 'At the heart of political representation lies the making and receiving of representative claims'. Thus, he avoids a direct answer to the question, let alone posing the question in the first instance: What is the purpose of making a representative claim? Ultimately, for Saward (2011, p. 80), 'politics is not so much the authoritative allocation of values as the contest over the sites, styles and bases of allocation, values and authority'. This view, as will be examined below, is of some significance when assessing the representative claims of demonstrators and 'the word from the street'.

\section{Legitimacy, representation and democracy}

When Saward (2010, p. 144) comes to examine the qualities of democratic representation, and democratic legitimacy specifically, he conceives of an open- ended process of legitimation in which there is 'acceptance by appropriate constituents, and perhaps audiences under certain conditions' of representative claims. An appropriate constituency is defined as those targeted by the claimant (the intended constituency) and those 'who judge that the claim is indeed for and about them' (the actual constituency). Thus, a judgement of the democratic legitimacy of representative claims is made by members of the appropriate constituency (who also judge 'whether they are part of the appropriate constituency that does the judging' (ibid., p. 151)). This 'provisionality' of judgement leads to a denial that 'the unelected are automatically illegitimate representatives' (ibid., p. 167). More particularly, it also questions any prior assumption that elected representatives are the sole or 'fully legitimate representatives' (ibid. emphasis in original).

Having briefly sketched the main contours of non-electoral representation, and the claims-based approach of Saward to democratic legitimacy, it is now time to examine these notions in the specific context of the 'word from the street' in the United Kingdom.

\section{Word from the Street: Making the Claim}

In making the case that a representative claim can be based on a 'massive and tangible demonstration of popular support', Saward (ibid., p. 99) cites the example of protests against the Iraq war. As he puts it:

[T]wo million people marching in a London demonstration against going to war against Iraq (without a second UN resolution) is a basis for representative claims for those leading or addressing such demonstrations to be representative of a significant swathe of public opinion.

If the Iraq demonstration of 15 February 2003 was unprecedented in size in recent UK history, any number of large public demonstrations could also be cited 
as examples of 'tangible public support' for some cause or other. Certainly, popular protests 'from the street' have been a recurring feature of representative politics in the United Kingdom. In recent times, streets in the major UK cities have reverberated to chants of 'we are the 99 per cent' (Occupy London Stock Exchange (Occupy LSX) demonstrations, 15 October 2011, 12 May 2012), or 'all together for public services' (TUC anti-cuts rally, 23 October 2010), or to the more delimited claims of students to 'fund our future' (NUS/UCU organised protest against student fees, 10 November 2010) or of public sector workers to 'save our pensions' (TUC Day of Action, 30 November 2011).

If, as Beetham (2003, p. 605) argues, 'numbers count in a democracy', the first difficulty in sustaining a non-electoral claim is knowing how many people 'on the street' are needed to demonstrate massive support. ${ }^{2}$ Certainly, the United Kingdom's coalition government, since May 2010, has been faced with large TUC-organised, anti-cuts marches of 400000 (police estimate 250 000) on 26 March 2011 and 25000 (police estimate 20000 ) on 30 November 2011. Yet, equally, the organisers and participants of smaller 'mass' demonstrations - for example, 'March for Jobs, Justice and Climate' (G20 demonstrations in London on 28 March 2009; police estimate 35000 protestors), or the 'Fund our Future' (student protest in November 2010, organiser's estimate 30 000, police estimate 15000 ) would maintain that they were making legitimate claims. Similarly, the 'performance protests' coordinated by, for example, UK Uncut in campaigns against, variously, corporate tax avoidance (with sit-ins at shops owned by Vodaphone, Topshop, Fortnum and Mason) and NHS cuts (the blocking of Westminster Bridge on 9 October 2011) constituted a clear, non- electoral, representative claim (see UK Uncut, 2011)

Even more markedly, Occupy LSX effectively deployed the slogan 'we are the 99 per cent' to 'imagine itself from the beginning as the broadest possible community of resistance - the 99 per cent, as against the 1 per cent' (Davis, 2011). And to make the claim in its Initial Statement:

We are of all ethnicities, backgrounds, genders, generations, sexualities dis/abilities and faiths. ... We stand together with occupations all over the world. ... We refuse to pay for the banks' crisis. We do not accept the cuts as either necessary or inevitable. ... We demand an end to global tax injustice and our democracy representing corporations instead of the people. (Occupy LSX, 2011a)

In terms of numbers, the Occupy LSX participants camped outside St Paul's Cathedral in the autumn of 2011, or demonstrating outside the Bank of England in May 2012, were counted in hundreds rather than thousands (but with a more numerous electronic 'presence' through Facebook, Twitter and other social media). ${ }^{3}$ However, numbers, as will be argued below, are, even in Saward's logic, not of paramount significance in making and sustaining a representative claim.

In making their respective claims, both anti-war and anti-capitalist protestors, in Saward's (2010, pp. 48-50) terminology, 'constructed a constituency' - in the sense 
of when 'speaking about' the negatives of war and capitalism, they also, indirectly, claimed to be 'speaking for' those in opposition to existing policies/systems. Hence, the slogans 'not in our name' or 'we are the 99 per cent' are broader collective claims beyond the individual claims of 'not in my name' or 'I am one of the 99 per cent'. Thus, the intended constituency is far broader than the actual constituency of those who recognise a claim through their presence in the act of protest (whether physically or virtually through electronic media). Correspondingly, the actual audience that receives the claim (through direct or indirect communication: speech, news media, social media and so on) and 'respond in some way' (ibid., p. 49) is but one segment of a wider intended audience to whom the claim is addressed - of other social movements, civil society organisations, opinion formers (media) and decision makers, both 'public' (members of formal political institutions) and 'private' (corporate/financial capitalist organisations). In both of the main examples used here - anti-war and anti-capitalist claims - the intended constituency and audience transcend the state boundaries of the United Kingdom, as in both cases there are parallel movements in other liberal representative democracies making similar claims.

\section{Evaluating claims}

However, making a claim is only part of an 'ongoing, dynamic process' (ibid., p. 44) of representation. A claim has to be evaluated by constituencies and audiences through 'acceptance acts' (ibid., pp. 151-153), which entail some assessment of the legitimacy of the claims made, and which can prompt negative and positive evaluations.

In the case of Occupy LSX, significant sections of the intended audience - 'the 99 per cent' - proved resistant to the representative claims: with only 39 per cent of a YouGov (2011a) sample supporting the aims of the protestors outside St Paul's, with 26 per cent opposing and 35 per cent not sure. However, within a few weeks, support for the protest was down to 20 per cent, with 46 per cent opposing and 33 per cent neither/do not know (YouGov, 2011b). In the 'percentage game', much was made of the fact that Occupy LSX did not, and could not, speak for 'the 99 per cent', with one comment posted in response to Occupy LSX's Initial Statement arguing that: 'your claim of representing the 99 per cent majority is an utter falsehood. A lot of us in the West - the majority - are HAPPY - read HAPPY - with the current system' (Occupy LSX, 2011a). In the case of anti-war claims in 2002-2003, while, at the time of the mass demonstrations, a large proportion of the UK public, 45 per cent of respondents to an ICM poll (fieldwork conducted 11-13 February 2003), agreed with the claim that Britain should not go to war, 40 per cent disagreed to the extent of believing that Britain should do so only if it obtained a fresh UN mandate. Yet, within less than a month of the 15 February demonstration, a subsequent ICM poll 
(28 March 2003; see also Lewis, 2004) reported that 52 per cent approved of military intervention in Iraq, with 34 per cent opposed to such action.

\section{Deciding Claims: Representation, Legitimacy and Democracy}

While anti-war and anti-capitalist demonstrators, along with others articulating 'the word from the streets', sought to construct, through their representative claims, wider constituencies within the public, and to appeal to wider audiences, through social networking and formal and informal media, their ultimate claim was to affect public policies (the outputs of the formal representative process) and to target an intended audience that was situated ultimately within the electoral representative process (no matter how indirectly that audience was approached).

The representative claims of anti-war and anti-capitalist demonstrators - in addition to making a positive claim to represent those opposed to war/capitalism - also contained the counter, negative claim that they:

no longer believed themselves to be represented by the actions of their government. One of the slogans of the anti-war movement - 'Not in my name' - made this point explicitly: individuals were seeking to sever the ties of representation by asserting their non-presence in the actions of the representatives. (Runciman, 2007, p. 101)

However, the claim of the government was of a different order: it did not claim to act 'in the name' of any particular individual. Instead, as Runciman (ibid.) observes, the government 'acted in the name of groups of individuals - "the people" - or ... in the British case, a kind of abstraction - "the state" - (or more technically, but also more absurdly, "the Crown")'. This introduces into the discussion the 'systemic' and 'collective' properties of political representation - in the form of 'the state' and of 'the people' - and directs attention towards the distinctiveness of the 'representative claims' of electoral representation.

\section{Distinctiveness of Electoral Representation}

As a first stage to understanding the distinctiveness of electoral representation, there is a need to examine the systemic nature of political representation and to appreciate that the systemic character of democratic representation is a 'complex, mixed bag of election, acceptance, acclamation and proposition' (Saward, 2010, p. 163). This is a view to which Mansbridge (2011, p. 628) and Rehfeld (2011, p. 640) subscribe, with both agreeing that 'representation at its broadest is systematic, in the sense of involving many different parts interacting with one another in interesting and complex ways' (Rehfeld, 2011, p. 640). Moreover, it is a view rooted in Pitkin's 
(1967, p. 221) belief that 'political representation is primarily a public, institutionalised arrangement involving many people and groups, and operating in the complex ways of large-scale social arrangements'. She argues that 'What makes it representation is not any single action by any one participant, but the overall structure and functioning of the system' (ibid.). In such a system, decision making, based on representative processes, has the capacity to resolve 'the conflicting claims of the parts, on the basis of the common interest in the welfare of the whole' (ibid., p. 217). As a process of adjudicating among, and reconciling, conflicting claims, political representation, or more accurately representative government, requires the construction of some common interest. For Pitkin (ibid., p. 224), the representative system 'must look after the public interest and be responsive to public opinion, except insofar as non-responsiveness can be justified in terms of the public interest. At both ends the process is public and institutional'. The most important institutional feature of representative government is that 'within a state, representation most commonly is ascribed to the legislature' (ibid., p. 227). It is within statal representative assemblies that the 'national interest is often formulated out of the rival claims of interests and localities within the state' (ibid., p. 218).

However, where the recent discussion has moved on from Pitkin's position is in the recognition of legitimate representative claims beyond the institutional configurations of elections and representative assemblies (Urbinati and Warren, 2008, p. 391). Yet, even Saward (2010, p. 167) acknowledges that his approach does not constitute a 'black-and-white alternative' to conventional conceptions of electoral democracy, and that 'elections and parliaments and the forms of due authorisation and accountability they offer still matter, of course'. From reading Saward (ibid. passim), the reasons why elective forms of representation 'still matter' are to be found, variously, in: decisional roles; perceived legitimacy, their positioning in 'a deep structure of more foundational or sedimentary representative claims of an institutional and (ultimately) constitutional sort'; symbolic representation of affectedness and unity where the legislature at state level 'brings the nation symbolically under one roof'; the extent and quality of public deliberation and 'deliberative accountability over time'.

\section{Decisional roles}

If democracy is taken to mean a system that enables citizens to participate in the making of decisions that affect them, then it is a form of government (see Held, 2006, p. 1; Urbinati, 2011, p. 23). In the case of representative government, if the democratic claims of the system are to be sustained, periodic elections have to be free, with an equal weight assigned to each vote and open to all enfranchised citizens who must have the competence to freely organise, speak and inform themselves of the alternatives (Rowbottom, 2010, pp. 7-13; Alonso et al 2011, p. 6). Added to this, 
majority rule has to be limited by a respect for minority rights (Sartori, 1987, p. 30). Moreover, elections bring conditionality to decision making. Elections implant uncertainty in the minds of representatives. They 'become periodic and dramatic demonstrations of the fact that possession of decision making power by representatives is contingent upon the continuing support of their electorate' (Judge, 1999, pp. 11-12).

\section{Perceived legitimacy}

The principle of equality encapsulated in voting and majority rule in the decision- making process produces, for 'procedural democrats' at least, results that 'are legitimate because the procedure is fair, not because the results are right' (Gutmann and Thompson, 1996, p. 26). There are two main emphases underpinning such a procedural view: authorisation and accountability. On the one side, elections for 'authorisation theorists' constitute a 'grant of authority' by which representatives are deemed to have the authority to deliberate and decide for others (Pitkin, 1967, p. 43). On the other side, 'accountability theorists' associate elections with holding representatives 'to account' or to be 'responsible' for their actions (ibid., p. 58). In effect, authorisation and accountability are collapsed into the single act of voting in elections, and this act holds the potential to be simultaneously both prospective and retrospective in orientation. In this 'conventional view' of representation, as Hayward (2009, p. 111) observes, notions of authorisation and accountability are 'understood to promote legitimacy in government under conditions in which all cannot participate directly in norm making'. More explicitly, Rehfeld (2006, p. 184) takes the authorization and accountability conditions identified by Pitkin (as her test of whether a person is a representative) to be equally 'limiting conditions of legitimate political representation'. Rehfeld stipulates that 'At a minimum, any account of legitimate representation will specify that the representative has the right (by virtue of authorisation) to participate in the process of legislation for the whole' (ibid., p. 188 added emphasis). At the level of the state, 'the reason a representative is accountable to this group [electors] ... is that she was authorized to act by this group'. And the 'action' in question, as noted above, is to make decisions, to 'participate in legislation' (ibid.).

These views have been reformulated recently and extended to include non-electoral forms of representative responsibility and accountability. In these reformulations, the essence of democratic legitimacy "is understood as "perceived legitimacy" as reflected in the acceptance of claims over time by appropriate constituencies under certain conditions' (Saward, 2010, p. 84). However, for present purposes, what is worthy of reiteration is that elections underpin the 'perceived legitimacy' of electoral representation, and provide recurring opportunities where the represented assent to being represented - whether assent is based on prospective or retrospective judgements of representatives' performance, or both. 


\section{'A deep structure of more foundational or sedimentary representative claims of an institutional and (ultimately) constitutional sort'}

Saward (ibid.) observes that those representative claims that are held to be compelling, or which have particular resonance among relevant audiences, 'will be made from "ready mades", existing terms and understanding that the would-be audiences at a given time will recognise'. This is of significance in differentiating electoral from non-electoral claims as one of the 'ready mades' of 'modern democratic constitutional design' is the 'centre-staging' of electoral representation, which is 'often now taken to be the paradigm of democracy'. In other words, electoral representation is identified as 'the received (and adaptable) frame within which we understand and interpret politics' (ibid., p. 178). This understanding impacts on the nature of claims made, with 'implicit claims' being most often made 'where the style or focus of the claims is familiar or rest upon accepted representational, often framing or constitutional, codes or institutions ... it matters hugely for us to acknowledge and understand claims we accept more or less unthinkingly' (ibid., p. 60). Such institutional codes, in turn, serve to constrain how 'representation is produced in particular places ... they influence the nesting of the representative claims' (ibid., p. 76). This nesting of claims along two key axes - formal-informal and explicit-implicit aligns power and strategic differentials with different representative claims:

surface claims that are able to rest upon deeper institutional and constitutional structures have a head start in terms of familiarity and perceived legitimacy. An elected politician, for example, generally has these deeper layers to support his other claims, while a protest group spokesperson may not. This is why the elected politician does not make his or her claim explicit much of the time - the structure of the system does a good deal of the work for him or her, but for the protest group spokesperson the same tends not to be true. (ibid., p. 65)

This argument has parallels with David Easton's notion of 'diffuse support'. Diffuse support for Easton (1965, p. 279) encompasses 'rudimentary convictions about the appropriateness of the political order of things' and generalised beliefs, no matter how inarticulate, 'that the authorities and the order within which they operate is right and proper' (ibid., p. 280). Such support is dependent on evaluations of the pertaining political 'rules of the game'; the continuing validation of which is underpinned by a

'legitimating ideology'. In the general case of liberal democracies, this ideology - as the 'ethical principles that justify the way power is organised, used and limited' (ibid., p. 292) - is enunciated in the language of electoral representation. In the specific case of the United Kingdom, 'the general belief, whether based on reason or not ... that public policy should be sanctioned and authorised by a representative body still pervades the ... polity' (Judge, 1999, p. 141 emphasis added). Such diffuse support is often tacit, even covert (Easton, 1965, p. 161), 
unthinking and possibly vacuous in empirical terms, but, nonetheless, profound in the sense that, as noted above, it gives the elected representative 'a head start in terms of familiarity and perceived legitimacy'.

\section{Symbolic representation of affectedness and unity 'one to all' where a legislature at state level 'brings the nation symbolically under one roof'}

Saward (2010, pp. 90-91) notes that at 'a strongly abstract level, representation in its most familiar contemporary guises, is "One to All" '... This oneness is positive. It provides an answer to the basic political question - who resolves issues when they are contested?' In the case of liberal democracies, it is a state's legislature that 'brings the nation together symbolically under one roof'. The lineage of such arguments is long, with Edmund Burke ([1774] 1801, p. 20) providing one of the clearest statements that the purpose of representation is to allow parliamentary representatives, through deliberation, to discover and enact the national interest. The symbolism and reality of contemporary parliamentary deliberation may be severely mismatched, but the symbolism has a practical significance in that it enables elected representatives, and especially governments derived from national representative assemblies, to claim to speak for the collective entity of 'the nation'. ${ }^{5}$ Saward (2010, p. 91) neatly captures this point:

The representation of two moderate abstractions - of the 'people' by the 'government' - is nested within the representation of two higher level abstractions - representation of 'the nation' by 'the state'. When they are (deliberately or by structural necessity) not accurately or fully representing people's views, political leaders always have the option of 'going up a level' and claiming to speak for the larger 'nation's' interests.

Although non-elected representatives may wish to claim that they too speak for a 'higher level' national interest (or even 'higher levels' beyond the state), what differentiates their claim from that of the elected representative is, in addition to the variables noted above, the manner in which the visions of the collective interest is constructed. This leads on to the consideration of the distinctiveness of elected representation in terms of 'the extent and quality of public deliberation' in the articulation of national interest.

'The extent and quality of public deliberation'/'deliberative accountability over time'

Saward (ibid., p. 109) is willing to contemplate that 'the primary democratic contribution of elections' rests in their contribution to 'the extent and quality of public deliberation'. This capacity of elections to secure deliberation is privileged 
'over and above their role as the core medium of democracy or a key guarantor of genuine representation'. However, the deliberative contribution of electoral representation can be extended beyond periodic election campaigns to include the intervening periods between elections, and the quality of intra-institutional deliberation within representative assemblies. Certainly, functionalistoriented legislative scholars in the United Kingdom conceived of a deliberative role for the House of Commons in terms of a 'continuous electoral campaign' (Crick, 1968, p. 26; see also Norton, 1991, p. 63). In the realm of political theory, Mansbridge (2003, p. 525) has counselled that when judgements are made of 'how well a political system meets democratic norms', some of the criteria should be 'deliberatively oriented and systemic'. However, what is distinctive about parliamentary deliberation is not simply a question of scale - of its macro-focus, rather than micro-focus - but its nature. Elected representatives in parliaments in modern representative democracies can be conceived as 'not simply facilitators of collective decision-making. Their decisions are taken in the name of the collective, and on its behalf' (Runciman, 2007, p. 105). This point is echoed in Eriksen and Fossum's (2011, p. 5) statement that:

Parliament enjoys a special status ... It embodies the idea of joint self- determination in that an elected body of responsible citizens is there to legislate in the name of all. ... The rationale of parliament rests on a 'dynamic-dialectic' of argument and counter-argument, of public debate and discussion. Deliberation is intrinsic to the mode of representation that parliaments are based on, and enables government by discussion.

This statement implicitly accepts the 'one to all' claim of elected representatives to act 'in the name of all' and links this claim to an institutionalised determination of the 'public will'. Eriksen and Fossum cite John Stuart Mill ([1861] 1910, p. 231) in support of their position, 'When it is necessary, or important to secure hearing and consideration to many conflicting opinions, a deliberative body is indispensable'. Similarly, Urbinati (2006, p. 134) maintains that 'citizens have to see and understand that they have something in common that unifies them', and political representation in parliament provides a 'unifying process' that enables sovereignty to be interpreted in terms of judgement and an imagined general will. Hence, for Urbinati (ibid., p. 59), any democratic theory of representation needs, 'as the point of departure', the 'fictional worlds of beliefs and judgement'. More categorically, Rehfeld (2005, p. 149) stipulates: 'There is simply no plausible justification for establishing a national representative legislature without some reference to the resulting good of all, whatever the good may turn out to entail'. Therefore, a prime purpose of parliament is to subject the conception of the national interest held by political representatives to, what Manin (1997, p. 191) calls, 'the trial of discussion'. In this view, representative government is a system in which 'everything has to be justified in debate'. 
Sidestepping here the protracted debate about the terminological differences between 'the national interest', 'the public will' and 'the general will', and how each is conceptualised and deployed in political theory; the important point for present purposes is that a national representative assembly is required to justify, through deliberation, the vision of the national interest propounded therein. In this respect, justification is a form of accountability or responsibility. What distinguishes electoral forms of representation, ultimately, is that 'only the elected have both deliberative and decision making power' (Urbinati, 2006, p. 15).

\section{Electoral Claims and Collective Decisional Processes in the United Kingdom}

From the preceding discussion, the distinctiveness of electoral representation has been identified as being based on conjoined and reinforcing assertions of the right of elected representatives to make decisions on behalf of, and in the name of, the abstract collectivity of the whole. At state level, the unity of 'one to all' is encapsulated in the concept of 'the national interest', formulated through deliberation and subject to recurring judgement by political representatives and by 'the people' through modes of authorisation, accountability and responsibility (including elections and formal and informal representative institutions). Systemic legitimacy derives as much from 'rudimentary convictions' and 'generalised beliefs' about the 'rules of the political game' as from positive evaluations of the actual actions and decisions of representatives. Taken together, it is the systemic, decisional and collective properties of electoral representation that distinguish it from non-electoral modes of representation.

Therefore, not surprisingly, it is precisely these properties that elected representatives invoke when confronted by protests and demonstrations on the street. Successive governments in the United Kingdom have maintained that 'the ability of citizens to campaign and protest is essential to a democracy' (Cm 7170, 2007, para 164; HC 608-iv, 2011, Q292). Yet, while maintaining the general right of protestors to voice representative claims 'from the street', governments have sought to delimit the legitimacy of those claims through the invocation of broader representative claims rooted in collective decisional processes. A classic example was provided by the then Home Secretary, Jack Straw, during the Fuel Protests in November 2000:

Peaceful protest can and does play an important role in drawing such concerns to the attention of Government and of Parliament. It is then for us in Government and Parliament to make choices ... Of course there are limits to peaceful protests. As for who runs Britain in a democratic society, it is a matter for Parliament and government. It is a matter for Parliament, through the ballot box, in reflecting the will of the people. There are many ways in which people 
can democratically express either their support for or opposition to the Government of the day. I celebrate, support and defend those avenues, but blocking motorways is not one of them. (HC Debates, 2 November 2000, cols 839, 849)

Approximately 10 years later, the Minister for Policing and Criminal Justice, Nick Herbert, echoed Straw's words during student demonstrations over tuition fees:

This Government have been clear that we are committed to supporting peaceful protest. Indeed, we included the restoration of the right to peaceful protest in our coalition agreement ...

[Parliament] is the place where democratic debate takes place over issues of public policy. No one questions the right of those students to march yesterday and to make their case, and 40000 of them did so peacefully. There is plenty of opportunity to debate policy, but there is neither a need nor any excuse for a minority to resort to violence. (HC Debates, 11 November 2010, col 457)

However, a deliberative claim, in isolation, is insufficient to distinguish electoral from non-electoral representation. Thus, Beetham (2003, pp. 601-602) noted in the case of the anti-war protests in 2003 :

What is remarkable about the Iraq controversy is that parliamentary deliberation only came into play long after an intense debate had been conducted in all kinds of other public settings ... It would be difficult to argue that the level of these parliamentary debates was in any way superior to those that had already taken place in many other public settings.

What is distinctive about parliamentary debate, however, is not any supposed superior quality, 6 but rather the institutionalised, judgemental nature of deliberation and the constant testing of the claim that decisions made by elected representatives (invariably, in practice, the decisions taken by government) represent 'the national interest'. ${ }^{7}$ Notably, opinion poll data in the United Kingdom suggests that there is overwhelming public support for the national representational focus of elected representatives. On average, 93 per cent of respondents to surveys conducted in the period 2004-2010 on behalf of the Committee on Standards in Public Life believed that MPs' decisions should be guided by 'what would benefit people living in the country as a whole' (Committee on Standards in Public Life, 2011, p. 30). This national focus outstripped both a party focus (84 per cent support) and a constituency focus (84 per cent support) in the same period. Similarly, if less markedly, 40 per cent of respondents in the Hansard Society's 2012 Audit of Political Engagement, when asked to select the most important function to them in terms of the work and role of the UK parliament, chose 'representing the United Kingdom's national 
interest' (Hansard Society, 2012, p. 47). This outstripped both 'representing the views of local communities' (28 per cent) and 'representing the views of individual citizens' (20 per cent).

The persistent testing of representative claims through parliamentary deliberation and the differentiation of partial from collective claims was evident in Tony Blair's response as Prime Minister to the fuel protests in 2000 . While incanting the right of fuel protestors to protest, he also pointed to the interconnectedness of public policy decision making and invoked the claim of government to represent the collective interest against the sectional claims of protestors (and for that matter, the partisan claims of Conservative politicians who supported the fuel protests):

it is important for the protesters to realise that were we to accede to their demands, that would have one of three effects, without any doubt whatever: interest rates, and therefore people's mortgages, would go up, or there would be less scope for helping pensioners, or we would have to reduce spending on public services. We will do what we can, but we will not do anything that puts at risk the strength of the economy or the support for essential public services. (HC Debates, 1 November 2000, col 708)

A decade later, David Cameron made almost exactly the same case:

Today, the protesters will be out again on the streets of London marching against this Coalition's plans for higher education. Banners will be waved, slogans chanted, placards hoisted. Of course these people have a right to protest ... A lot has been said in recent weeks about what is in the interests of students ... Our Coalition partners have had a lot of stick for supporting this policy but their opponents should understand this: responsible politics is not about peddling fantasy policies without looking at the price tag and pleasing any crowd you're playing to. It means making hard decisions in the national interest. (London Evening Standard, 30 November 2010)

In the case of the Iraq and Afghanistan wars, there has been a fundamental cross- party claim that elected representatives in Westminster represent the national interest (even though there has been fierce intra-party contestation of that claim). When in opposition, both major UK parties have acknowledged the right of the serving government to act in the collective interest. At the time of the Iraq invasion in 2003, the then Conservative Party leader, lain Duncan Smith, declaimed:

There are matters at stake that rise above party politics. It is the duty of the Government to act in the national interest, and it is the duty of the Opposition to support them when they do so. The Prime Minister is acting in the national interest today. That is why he is entitled to our support in doing the right thing. (HC Debates, 18 March 2003, col 779) 
In the face of sporadic street protests in 2011 against the continued UK deployment of troops in Afghanistan, Jim Murphy, Labour's Shadow Defence Secretary, echoed almost exactly the views of Duncan Smith:

On Afghanistan, I want to say to this House, our forces and, importantly, our enemies that the Government will always have the support of the Opposition when they do the right thing ... We will continue to conduct debates on Afghanistan, in particular, in a spirit of comradeship, for that is in the national interest above all party interest. (HC Debates, 10 January 2011, col 54)

David Spellar, a Labour Shadow Foreign Office Minister, later repeated this view and also made clear the accountability dimension of electoral representation:

The role of the Opposition in these matters is to support the national interest and, in particular, to take a long-term view of the issues ... However, on behalf of the country ... we must also hold the Minister and the Government to account for their performance. (HC Debates, 6 July 2011, col 1615)

Similarly, in the face of the continuing financial crisis and anti-capitalist street protests, a baseline consensus on the significance of the financial sector to the United Kingdom's economy was apparent across the major UK parties in Parliament. In part, this was a reflection of a wider post-Thatcher, neoliberal economic consensus (for a succinct overview, see Gamble, 2009, pp. 450-462). Yet, even with such a baseline consensus, political representatives wished to test in Westminster specific claims that its constituent elements reflected 'the national interest'. Thus, even supporters of the Government's overall economic strategy still demanded that the claim to act in 'the national interest' should be justified:

As MP for the City of London, I reluctantly accept that I have no choice but broadly to support the UK Government's proposal to underwrite further funds to the IMF. Nevertheless, I regard it as a matter that must be addressed not by the Executive alone but also here in Parliament. If the UK taxpayer is to be further exposed to IMF loans and guarantees, that must happen only after a statement from the Prime Minister outlining why such a course of action is in the national interest ... in Parliament. In my view, nothing less will do. (Mark Field, HC Debates, 15 November 2011, col 194WH)

Perhaps not surprisingly, despite a basic consensus being shared by successive UK governments on a regulatory regime for the United Kingdom's financial and banking sectors - framed so as not to inhibit the international competitive advantage of these sectors (see Gamble, 2009, p. 458) - the deluge of scandals associated with these sectors led, with increased intensity, to the refraction, through party political lenses, of the claim that such a regulatory regime represented the 
interest. As the Leader of the Labour party, Ed Miliband noted with clear partisan intent:

Whenever these scandals happen, [the Prime Minister] is slow to act and he stands up for the wrong people. The question people are asking is, 'Who will act in the national interest, rather than the party interest?' His is a party bankrolled by the banks. If he fails to order a judge-led inquiry [into the banking industry following the scandal associated with the manipulation of the Libor rate], people will come to one conclusion: he simply cannot act in the national interest. (HC Debates, 4 July 2012 , col 912)

A defining characteristic of electoral representation, therefore, is that claims to represent the national interest have to be publicly defended. It is insufficient for a government to claim that its conception of the collective interest is legitimate simply by virtue of having made a decision. What has to be guarded against is that 'In saying that they are legitimate because they are governing in the national interest, the Government are judge and jury in their own case as they determine the national interest' (Lord Plant, HL Debates, 20 January 2011, col 567). The important normative expectation of political representation is that elected governments are subject to an institutionalised form of 'public reasoning' of defending their conception of the public good in parliaments. This circles back to Rehfeld's contention, noted above, about the linkage functions of representative assemblies and their capacity to legislate in the national interest. Rehfeld (2005, p. 149 emphasis in original) argued: 'the proper function of any national legislature is to pass laws in the nation's best interest whatever that means rather than laws that serve "[a particular person's] interests" or the "interests of [a locality]", even if it turns out that either of these is exactly the same as the national interest'. Therefore, in effect, the difference between non-electoral representation and electoral representation, and between claims based on sectional interest and general interest, is that the former is a claim for compatibility, or at best congruence, with a conception of 'the national interest', whereas the latter is a claim of exact synonymity with 'the national interest'.

\section{Conclusion}

In essence, this article rephrased the fundamental questions raised by Beetham: Is it legitimate for a democratically elected government to ignore public opinion [as expressed through mass demonstrations and protests]? Is it democratic for it to do so? Beetham's own answers are unequivocally 'no' and 'no'. However, in rephrasing these questions - to focus on the nature of the representative claims made, the audiences addressed and the acceptance acts associated, respectively, with electoral and non-electoral representation - the answers are more equivocal. 
In this rephrasing, non-electoral claims, based on 'massive and tangible demonstration of popular support' and the expression of the 'word from the street', serve to 'construct a constituency' and address an audience beyond formal representative institutions and, in many instances, beyond the boundaries of the UK state. Undoubtedly, the 'word from the street' has its own claim to legitimacy. However, in Saward's (2011, p. 90) formulation, 'democratic legitimation is an attribute of certain claims (where sufficient evidence of chosenness is present)'. Although the 'chosenness' of elected representatives is distinct and formally acknowledged through the outcomes of a ballot, 'chosenness' does not help much in advancing Saward's (ibid., p. 91) general case that the legitimacy of nonelectoral representative claims rests in 'contingent judgements of chosenness', or of his specific case that the 'word from the street' captures 'the idea that the interests that are claimed to be represented emerge from specific grassroots techniques or events' (ibid., p. 99). If the 'chosenness' of protestors and demonstrators (especially those leading and addressing such gatherings) is contingent upon their claim to represent constituencies beyond those present on the streets, and if their democratic legitimacy is contingent upon recognition of 'their chosenness in the eyes of such wider constituencies', then the extreme provisionality of such non-electoral representative claims - and the difficulty of demonstrating 'regular renewal' of chosenness - restricts their capacity to claim democratic legitimation for their actions. If, as Saward (ibid.) contends, 'what distinguishes democratic claims is that they demonstrate a sufficient degree of "chosenness"', then the democratic claims of elected representatives, as demonstrably and quantitatively, 'chosen' through the ballot is distinctly different from the non-electoral claims of protestors and demonstrators. ${ }^{8}$

Ultimately, however, an assessment of legitimate democratic claims is nested in a pre-existing and 'ongoing, dynamic process' of complex, systemic modes of representation that institutionalise collective decisional roles and require formal justification of those decisions in elected representative institutions. The latter can draw on conceptions of legitimacy framed by accepted constitutional codes, established representational claims and 'rudimentary convictions about the appropriateness of the order of things'. Indeed, the acceptance of representative claims 'more or less unthinkingly' by the majority of the public gives elected representatives a 'head start' in terms of perceived legitimacy. In this sense, the distinction to be drawn between electoral and non-electoral representative claims, and the nature of acceptance acts associated with the resolution of conflicting claims, might very well lead to affirmative answers in response to Beetham's questions.

\section{Notes}

1 Although the discussion of representative claims is couched in universalistic terms, Saward $(2010$, p. 179) is aware that political principles gain their meaning and significance in particular political 
'contexts. He notes that there will be considerable differences between 'repertoires of claim-making' in different political systems (ibid., p. 87). The distinctive characteristics of the United Kingdom's political system - of the continuing institutional residues of the Westminster model and notions of parliamentary sovereignty - have an impact on representational practices, and this distinctiveness allows a case to be made for examining the broader concept of representative claims within the specific context of this particular political system.

2 The figures presented here relate to demonstrations in London (see www.guardian.co.uk/news/datablog/ 2011/mar/28/demonstrations-protests-uk-list). In many instances, marches in London have parallel marches in other UK cities, for example, The Guardian estimated that 15000 and 30000 protestors marched through Birmingham and Manchester, respectively, in support of the TUC's Day of Action on 30 November 2011. On the same day, an estimated 2000000 public sector workers took part in strike action. It should also be noted that the organisers' estimates of attendance are often at variance with police estimates: the police estimate for the anti-war demonstration in London on 15 February 2003 was 750000.

3 When accessed on17 November 2011,Occupy LSX had 20662 followers on Twitter and UKUncut had 35617 followers; the Facebook 'like this' count was: Occupy LSX 31564 and UK Uncut 32556 . The comparative figures for the Conservative Party and the Labour Party were respectively 55264 followers and 43749 followers on Twitter; and Facebook 'like this': Conservative party 149894 and Labour party 114641.

4 The wording of the question in this second poll was: Do you support or oppose the Occupy London protest outside St Paul's Cathedral? The wording of the question in the first poll was: Regardless of whether or not you agree with them protesting outside St Paul's Cathedral, do you support or oppose the aims of the protesters?

5 Historically,under the constitutional doctrine of parliamentary sovereignty, the UK parliament served as a means of integrating the United Kingdom and as a symbol of state unity. As such, the Westminster parliament claims to represent, and therefore to speak for, the multinational state of the United Kingdom. Since the post-1999 devolution settlement, however, the elected National Assembly of Wales and the Scottish Parliament claim, respectively, to speak for 'the national interest' of the nations of Wales and Scotland in devolved policy areas. Nationalists within these devolved institutions also assert a claim that the devolved legislatures have a right to speak for a 'national interest' in areas beyond their immediate legislative competences. In particular, Alex Salmond, as Scotland's First Minister, has been adept at counterposing Scotland's national interest against the UK government's articulation of the United Kingdom's national interest. See, for example, Official Report, Scottish Parliament, 1 December 2011, col. 4226.

6 A feature of the theories of Burke and John Stuart Mill is a defence of the superior quality of deliberation in representative assemblies, see Judge (1999, pp. 47-57).

7 This is 'a claim' to represent 'the national interest'. Obviously, the concept of 'national interest' is socially constructed and contestable. What is distinctive about the claim to represent, or the construction of, the 'national interest' made by elected representatives, however, is that it is legitimated through the process of election and subjected to repeated testing in the 'constant electoral campaign' of institutionalised parliamentary deliberation. This does not mean that such constructions are objective, non-partisan or non-reflective of broader power differentials in economic and social relations. It simply means that these constructions are subject to electoral testing. Significantly, for this discussion, the Cabinet Office recently maintained that the basis of the post-2010 UK coalition government was 'a shared assessment by the two parties forming the Government on where the national interest lay ... The Programme for Government ... represents the Government's strategic assessment of the actions needed to secure the UK's national interest' (HC 1625, 2012, Ev 72). In identifying six strategic aims to promote the national interest, the government maintained that these aims were 'widely shared across the UK political spectrum'. While recognising that there were significant party differences as to how these aims were to be translated into policies and implemented, Cabinet Office minister, Oliver Letwin, 
nonetheless, maintained that any government's conception of the strategic aims to be pursued in the national interest 'have been subject to a very considerable - in fact, the toughest - democratic test [at elections]' (HC 1625, 2012, Q286-287). Indeed, recognition that 'elected representatives are best placed to articulate an understanding' of how the national interest is conceived, the political limitations upon national strategy and 'what the electorate will find acceptable' was highlighted by the House of Commons' Public Administration Select Committee (HC 435, 2010, paras 46-47). This was not an uncritical acceptance of the government's definition of the national interest or its specification of national strategic aims. Indeed, in the Committee's opinion, the government's statement of aims might have been 'well-meaning but [was] too meaningless to serve any useful purpose' (HC 1625, 2012, para 31). The Committee also acknowledged that while 'it is elected politicians and ministers that have the democratic legitimacy' (HC 435, 2010, para 47) to pursue their conception of the national interest, 'elections are only a small part of the conversation on the fundamental questions which determine the future of the country' (HC 1625, 2012, para 44). The point made here is that within that conversation, elected politicians claim to have the authoritative and authentic voice and base that claim on their elected status.

8 Many protest social movements profoundly reject the concept of leadership, or for that matter, representation itself (see for example Occupy LSX, 2011b).

\section{References}

Alonso, S., Keane, J. and Merkel, W. (eds.) (2011) Rethinking the future of representative democracy. In: The Future of Representative Democracy. Cambridge, UK: Cambridge University Press: pp. 1-22.

Beetham, D. (2003) Political participation, mass protest and representative democracy. Parliamentary Affairs 56(4): 597609.

Burke, E. (ed.) [1744] (1801) Speech to the electors of Bristol. In: The Works of the Right Honourable Edmund Burke, Vol. 3. London: Rivington.

Cm 7170. (2007) The Governance of Britain. London: Stationery Office.

Committee on Standards in Public Life. (2011) Survey of Public Attitudes Towards Conduct in Public Life in 2010. London: Committee on Standards in Public Life.

Crick, B. (1968) The Reform of Parliament. London: Weidenfeld and Nicolson.

Davis, A. (2011) The 99\%: A community of resistance. Comment is free. The Guardian, 15 November.

Easton, D. (1965) A Systems Analysis of Political Life. Chicago, IL: University of Chicago Press.

Eriksen, E.O. and Fossum, J.E. (2011) Representation Through Deliberation: The European Case. Oslo, Norway: ARENA, RECON Online Working Paper 2011/14, http://www.reconproject.eu/main.php/ RECON_wp_1114.pdf?fileitem=5456472.

Gamble, A. (2009) British politics and the financial crisis. British Politics 4(4): 450-462.

Goodin, R.E. (2004) Representing diversity. British Journal of Political Science 34(3): 453-468.

Gutmann, A. and Thompson, D. (1996) Democracy and Disagreement. Cambridge, MA: Harvard University Press.

Hansard Society. (2012) Audit of Public Engagement 9: The 2012 Report. London: Hansard Society.

Hayward, C.R. (2009) Making interest: On representation and democratic legitimacy. In: I. Shapiro, S.C. Stokes, E.J. Wood and A.S. Kirshner (eds.) Political Representation. Cambridge, UK: Cambridge University Press, pp. 111-135.

HC 435. (2010) Who Does UK National Strategy. First Report of Session 2010-11. Public Administration Select Committee, House of Commons. London: The Stationery Office.

HC 608-iv. (2011) Evidence from the Prime Minister, The Liaison Committee, House of Commons, 8 November 2011. London: The Stationery Office.

HC 1625. (2012) Strategic Thinking in Government: Without National Strategy, Can Viable Government Strategy Emerge? 24th Report of Session 2010-12, Public Administration Select Committee, House of Commons. London: The Stationery Office. 
Held, D. (2006) Models of Democracy, 3rd edn. Cambridge, UK: Polity.

Judge, D. (1999) Representation: Theory and Practice in Britain. London: Routledge.

Lewis, J. (2004) Television, public opinion and the war in Iraq: The case of Britain. International Journal of Public Opinion Research 16(3): 295-310.

Manin, B. (1997) The Principle of Representative Government. Cambridge, UK: Cambridge University Press.

Mansbridge, J. (2003) Rethinking representation. American Political Science Review 97(4): 515-528.

Mansbridge, J. (2011) Clarifying the concept of representation. American Political Science Review 105(3): 621-630.

Mill, J.S. ([1861] 1910) Considerations on Representative Government. London: Dent.

Norton, P. (1991) The Commons in Perspective. Oxford: Martin Robertson. Occupy LSX. (2011a) Initial Statement. Occupy London, http://occupylsx.org/?page_id=575.

Occupy LSX. (2011b) Statement of Autonomy. Occupy London, available at http://occupylsx.org/? page_id=3349.

Phillips, A. (1995) The Politics of Presence. Oxford: Oxford University Press.

Pitkin, H.F. (1967) The Concept of Representation. Berkeley, CA: University of California Press.

Rehfeld, A. (2005) The Concept of Constituency: Democratic Representation, Democratic Legitimacy,and Institutional Design. Cambridge, UK: Cambridge University Press.

Rehfeld, A. (2006) Towards a general theory of political representation. The Journal of Politics 68(1): 1-21.

Rehfeld, A. (2011) The concepts of representation. American Political Science Review 105(3): 631-41.

Rowbottom, J. (2010) Democracy Distorted: Wealth, Influence and Democratic Politics. Cambridge, UK: Cambridge University Press.

Runciman, D. (2007) The paradox of political representation. The Journal of Political Philosophy 15(1): 93-114.

Sartori, G. (1987) The Theory of Democracy Revisited. Chatham, NJ: Chatham House.

Saward, M. (2006) The representative claim. Contemporary Political Theory 5(3): 297-318.

Saward, M. (2010) The Representative Claim. Oxford: Oxford University Press.

Saward, M. (2011) The wider canvas: Representation and democracy in state and society. In: S. Alonso, J. Keane and W. Merkel (eds.) The Future of Representative Democracy. Cambridge, UK: Cambridge University Press, pp. 74-95.

UK Uncut. (2011) About, http://www.ukuncut.org.uk/about/ukuncut.

Urbinati, N. (2006) Representative Democracy. Chicago, IL: University of Chicago Press.

Urbinati, N. (2011) Representative democracy and its critics. In: S. Alonso, J. Keane and W. Merkel (eds.) The Future of Representative Democracy. Cambridge, UK: Cambridge University Press, pp. 23-49.

Urbinati, N. and Warren, M.E. (2008) The concept of representation in contemporary democratic theory.

Annual Review of Political Science 11: 387-412. YouGov. (2011a)

YouGov/Sunday Times Survey $\quad$ Results, $\quad$ Fieldwork: $27-28 \quad$ October, http://cdn.yougov.com/cumulus_uploads/document/4024/Sunday\%20Times\%20Results\%20111028\%20VI\%20and\% 20Trackers\%20website.pdf. YouGov. (2011b)

YouGov/Sunday Times Survey Results, $\quad$ Fieldwork: 4 November, http://cdn.yougov.com/cumulus_uploads/document/2011-11-04/YG-Archives-Pol-Sun-results-041111.pdf. Young, I.M. (2000) Inclusion and Democracy. Oxford: Oxford University Press. 